\title{
Characterization of Atmospheric Gaseous Components in Abattoir Operation Site in Ogbor-Hill Aba, Abia State, Nigeria
}

\section{Ubuoh EA ${ }^{1^{*}}$, Uchendu $\mathrm{UI}^{2}$ and Kanu $\mathrm{C}^{3}$}

${ }^{1}$ Department of Environmental Management and Toxicology (EMT), Michael Okpara University of Agriculture, Umudike, Abia State, Nigeria ${ }^{2}$ College of Natural Resources and Environmental Management (CNREM), Michael Okpara University of Agriculture, Umudike, Abia State, Nigeria ${ }^{3}$ Michael Okpara University of Agriculture, Umudike(MOUAU), Abia State, Nigeria

\begin{abstract}
Ambient air pollutant has become a major problem in most town in Nigeria. The study aimed at assessing the spatiotemporal variation of abattoir operation on the ambient air quality in Ogbor-hill Aba. The study was carried out within 3 months with emphasis on seven pollutant that originated from abattoir operation at graded distance. From the result, three of the criteria pollutants monitored, $\mathrm{SO}_{2}, \mathrm{NO}_{2}$ and $\mathrm{PM}_{10}$ recorded the mean values of $613.25 \mu \mathrm{g} / \mathrm{m}^{3} .699 .05$ $\mu \mathrm{g} / \mathrm{m}^{3}$ and $1966.67 \mu \mathrm{g} / \mathrm{m}^{3}$. these exceeded the national ambient air quality standard (NAAQS) by $13 \%, 14.31 \%$ and $76.27 \%$ respectively. With a statistical model, the PSI value for the pollutants were found to be $\mathrm{SO}_{2}\left(588.81 \mu \mathrm{g} / \mathrm{m}^{3}\right), \mathrm{NO}_{2}$ $\left(878.62 \mu \mathrm{g} / \mathrm{m}^{3}\right)$ and $\mathrm{PM}_{10}\left(585.91 \mu \mathrm{g} / \mathrm{m}^{3}\right)$ which signifies elevated concentration of pollutant. Further comparisons were made using WHO and FMENV, the result of the pollutants exceeded their approved standards. On subjection to ANOVA, $\mathrm{SO}_{2}$ and $\mathrm{NO}_{2}$ exerted a significant effect at $p \leq 0.01$ and $\mathrm{PM}_{10}$ proved significant at $\mathrm{p} \leq 0.05$. the entire result indicated a very serious health implication on the public especially those with existing health challenges. The high concentration of these pollutants on the ambient air triggers health alters and every one may experience more serious health effect on continuous exposure. To mitigate this emission, the abattoir operators must adopt a hygienic and modern treatment of effluent before disposal. Excess waste can be used for agricultural purposes. Further abatement measures may require the relocation of the abattoir far from residential areas.
\end{abstract}

Keywords: Ambient air quality; Abattoir; PSI; Pollutant

\section{Introduction}

Air pollution is the introduction of substances into the atmosphere that harm or cause discomfort to human and other living and non-living things. Ambient air pollution has constituted serious threat to man and his environment during production processes that emits obnoxious gases into the atmosphere. Globally abattoirs are recognized as a major source of air pollutant [1]. The impact in the ambient air varies from relatively minor, if mitigating measures are applied to extreme where emission results to public menace [2]. In an abattoir operational system where incinerators are used to burn waste and carcasses, a range of air pollutants are released into the atmosphere. Such pollutants include Sulphur dioxide $\left(\mathrm{SO}_{2}\right)$, Nitrogen dioxide $\left(\mathrm{NO}_{2}\right)$, particulate matter $\left(\mathrm{PM}_{10}\right)$, Carbon monoxide (CO), Carbon dioxide $\left(\mathrm{CO}_{2}\right)$ and other volatile organic compounds VOCs [3]. On the other hand, the smoke emitted from the incinerator may also constitute a serious nuisance on the atmosphere. These odoriferous compounds produced because of abattoir operation affects the characteristics of the ambient air quality rendering it unsuitable for human inhalation [4].

A serious odour problem was reported from poorly managed pond at a chicken abattoir in North America [5]. Vehicle transporting livestock to and from abattoir sites may cause a serious odour problem as they pass through residential areas and during offloading at the abattoir sites. All these activities put together emits a great portion of air pollutants into the surrounding ambient air thereby altering its quality. Despite these environmental problems, the construction of abattoirs is on the increase, a recent study contended that abattoir operation contributes so much on air pollution problem in Nigeria. Abattoir emission also contributes to global problem caused by greenhouse gas emission. Emissions are variable in space and time and in how they interact within the various processes and media affected [6]. Abattoir also consumes fuel for energy production thereby emitting $\mathrm{CO}_{2}, \mathrm{NOx}, \mathrm{SO}_{2}$ and particulates.

Till date, the extent of detrimental impact of abattoir operation on the ambient air quality are yet an unknown issue in Nigeria. The nature of emission produced from an abattoir operation introduces so much odoriferous compounds into the atmosphere and this in turn affects the air quality making it unbearable for man. Most respiratory track infections experienced by people in the urban areas especially those closer to abattoir sites attributes to ambient air pollution. The most alarming case is the high incidence of chronic lung infection among abattoir operators [7]. Abattoir are one of industries that releases appreciable amount of organic and inorganic air pollutants such as hydrogen sulphide $\left(\mathrm{H}_{2} \mathrm{~S}\right)$, Methanethiol, Ammonia, Di methyl sulphide etc. during the heating of animal tissues. These pollutants with high concentration can be objectionable and pose health effect such as headache, nausea, eye irritation paralysis and even death, therefore it must be controlled [7]. Volatile organic compounds such as $\mathrm{SO}_{2}, \mathrm{NO}_{2}$ and $\mathrm{PM}_{10}$ can cause irritation in the eye, nose and throat, in several cases leads to headache, nausea and loss of coordination. In long run, some of these are suspected to cause damage to the liver and other parts of the body which may even lead to death. Children and aged adults are most vulnerable to these organic pollutants.

This objective of this research is to analyse the spatiotemporal variation of abattoir operation on ambient air quality in Ogbor hill aba, Abia state, also to characterize the ambient air quality in the abattoir at graded distance and finding a possible solution or mitigative measures for sustainable use of abattoir. Hence, this research covers the impact of

*Corresponding author: Ubuoh EA, Department of Environmental Management and Toxicology (EMT), Michael Okpara University of Agriculture, Umudike, Abia State, Nigeria, Tel: +23408037639777; E-mail: ubuohemmanuel@yahoo.com

Received May 13, 2017; Accepted May 22, 2017; Published June 14, 2017

Citation: Ubuoh EA, Uchendu UI, Kanu C (2017) Characterization of Atmospheric Gaseous Components in Abattoir Operation Site in Ogbor-Hill Aba, Abia State Nigeria. J Environ Anal Toxicol 7: 474. doi: 10.4172/2161-0525.1000474

Copyright: @ 2017 Ubuoh EA, et al. This is an open-access article distributed under the terms of the Creative Commons Attribution License, which permits unrestricted use, distribution, and reproduction in any medium, provided the original author and source are credited. 
Citation: Ubuoh EA, Uchendu UI, Kanu C (2017) Characterization of Atmospheric Gaseous Components in Abattoir Operation Site in Ogbor-Hill Aba, Abia State, Nigeria. J Environ Anal Toxicol 7: 474. doi: 10.4172/2161-0525.1000474

Page 2 of 4

abattoir operation on atmospheric chemistry within Ogbor Hill and its environs in Aba.

\section{Materials and Methods}

\section{Environmental setting}

The research was carried out in Ogbor hill Aba in Aba South Local Government Area of Abia State, Nigeria. The area lies between latitude $5^{\circ} 07^{\prime} \mathrm{N}$ and $7^{\circ} 23^{\prime} \mathrm{E}$ and longitude $5^{\circ} 117^{\prime} \mathrm{N}$ and $7^{\circ} 367^{\prime} \mathrm{E}$ with an estimated population of $1,020,900$ as at 2004 population census. The indigenous people of Aba are the Ngwas and are mostly Christians. Aba is known for its craftsmen. There are several abattoir sites in Ogbor hill Aba, and they dispose their waste into the Aba river and its environ. The climatic condition of the area has its parameter as; temperature range of $21^{\circ} \mathrm{C}$ and $27^{\circ} \mathrm{C}$, relative humidity ranges between $60-80 \%$. The area lies within the sub-equatorial, sub-humid region with March to October as rainy season and November to February as dry season. Annual average rainfall is about $2200 \mathrm{~mm}$.

\section{Sampling design, collection and preparation}

Samples were collected from five sampling points in Ogbor hill Aba. The points were designated as $\mathrm{SP}_{1}, \mathrm{SP}_{2}, \mathrm{SP}_{3}, \mathrm{SP}_{4}, \mathrm{SP}_{5}$ with $\mathrm{SP}_{5}$ serving as the control. Each sampling point were located at distance of $50 \mathrm{~m}$ from each other however the control was located at $200 \mathrm{~m}$ from the study area [6]. Data collection was done insitu in accordance with a fixed sampling schedule at an hourly interval in the prevailing wind direction but in the downwind direction for the control sample point. Multiple sampling points were required to ensure reasonable coverage of the area and replicate measurement made at each sampling point. Air sampling was conducted focusing mainly on three criteria pollutants, $\mathrm{SO}_{2}, \mathrm{NO}_{2}$ and $\mathrm{PM}_{10}$ since they constitute a large portion of emission from abattoir site [3]. Other pollutant measured includes $\mathrm{CO}, \mathrm{CO}_{2}$, VOCs and $\mathrm{H}_{2} \mathrm{~S}$. measurement was carried out using a multi gas analyser (2002 model) with electrochemical measuring principles and complete conditioning system. Other monitoring equipment used includes Gasman Model $19773 \mathrm{H}$ for VOCs and $\mathrm{H}_{2} \mathrm{~S}$ and Multi REA plus (PCM 50) for CO, $\mathrm{CO}_{2}$ and relative humidity temperature and wind speed were also measured. Data were collected within 8:30 am and 4:30 pm on 8-hourly with one hour interval on daily basis during the three-month period. Samples were collected on dry and wet days to help assess the influence of humidity and dry atmosphere on ground level concentration of the measured pollutants.

Descriptive statistics were used to present data in numerical and tabular forms. Data were analysed using mixed effect models with random subject effect for repeated measurement. In the first level of analysis, linear and logistic model were applied for the pollutant gas combined to know whether association exists. The test homogeneity in mean variance of the concentration levels of monitoring gases across the sampling station was conducted with analysis of variance (ANOVA). The pollutants standard (PSI) was calculated for an overall assessment of air quality using the procedure adopted by EPA [8]. The value of PSI helped to know whether air quality was improving or worsening in the area and the pollutant(s) exceeding National Ambient Air Quality Standard (NAAQS), WHO and FMENV. All statistical analysis was done using the statistical model approved by EPA [4] to calculate the PSI value of the main pollutants (Tables 1-5)

A statistical model was applied to calculate the PSI of each pollutant, using the formula in accordance to EPA [4].

$$
\text { Lp }=[\text { Lhi-Llo] (CP-Bplo)+Llo/BPhi-Bplo }
$$

\begin{tabular}{|c|c|c|c|c|c|}
\hline S No & Index/value & Descriptor & $\mathbf{S O}_{\mathbf{2}}$ & $\mathbf{N O}_{\mathbf{2}}$ & $\mathbf{P M}_{\mathbf{1 0}}$ \\
\hline 1 & $0-100$ & Good & $0-80$ & $0-80$ & $0-200$ \\
\hline 2 & $100-200$ & Moderate & $81-367$ & $81-180$ & $201-260$ \\
\hline 3 & $200-300$ & Poor & $368-786$ & $181-564$ & $261-400$ \\
\hline 4 & $300-400$ & Very Poor & $787-1572$ & $565-1272$ & $401-800$ \\
\hline 5 & $400-500$ & Severe & $>1572$ & $>1272$ & $>800$ \\
\hline
\end{tabular}

Source: Goyal and Kumar

Table 1: Shows the break point for PSI (AQI) in $\mu \mathrm{g} / \mathrm{m}^{3}$.

\begin{tabular}{|c|c|c|}
\hline API & Air pollution level & Health implications \\
\hline $0-50$ & Low & None expected \\
\hline $51-100$ & Medium & None expected for general population \\
\hline $101-200$ & High & $\begin{array}{l}\text { Acute health effect is not expected but } \\
\text { chronic effects may be observed if one is } \\
\text { persistently exposed to such level }\end{array}$ \\
\hline $201-300$ & Very high & $\begin{array}{l}\text { People with existing heart or respiratory } \\
\text { illness may notice mild aggravation } \\
\text { of their health condition. Generally, } \\
\text { healthy individuals may also notice some } \\
\text { discomfort. }\end{array}$ \\
\hline $\begin{array}{c}301-500 \text { and } \\
\text { above }\end{array}$ & Severe & $\begin{array}{l}\text { People with existing heart or respiratory } \\
\text { illness may experience significant } \\
\text { aggravation of their symptoms. There } \\
\text { may also be widespread symptoms in } \\
\text { the healthy population e.g. Eye irritation, } \\
\text { coughing, sore throat, etc. }\end{array}$ \\
\hline
\end{tabular}

Source: FEPA

Table 2: Shows the Value and description of standard pollutant index (PSI) currently referred to as air quality index (AQI) by the US EPA.

\begin{tabular}{|c|c|c|c|c|c|}
\hline Parameter & In Situ & $\mathbf{0 - 5 0} \mathbf{~ m}$ & $\mathbf{5 0 - 1 0 0 ~} \mathbf{~}$ & $\mathbf{1 0 0 - 1 5 0 ~} \mathbf{~}$ & $\mathbf{1 5 0 - 2 0 0 ~} \mathbf{~}$ \\
\hline $\mathrm{SO}_{2}\left(\mu \mathrm{g} / \mathrm{m}^{3}\right)$ & 853.33 & 826.34 & 480.00 & 253.34 & 80.00 \\
$\mathrm{NO}_{2}\left(\mu \mathrm{g} / \mathrm{m}^{3}\right)$ & 893.30 & 840.00 & 542.86 & 520.00 & 173.34 \\
$\mathrm{PM}_{10}\left(\mu \mathrm{g} / \mathrm{m}^{3}\right)$ & 2733.34 & 2333.34 & 1733.34 & 1066.67 & 160.00 \\
$\mathrm{H}_{2} \mathrm{~S}\left(\mu \mathrm{g} / \mathrm{m}^{3}\right)$ & 1306.67 & 893.34 & 273.34 & 333.33 & 93.34 \\
$\mathrm{CO}\left(\mu \mathrm{g} / \mathrm{m}^{3}\right)$ & 64186.67 & 81360.00 & 85920.00 & 26186.67 & 24613.34 \\
$\mathrm{CO}\left(\mu \mathrm{g} / \mathrm{m}^{3}\right)$ & 273600.00 & 271600.00 & 165040.00 & 141493.34 & 121373.33 \\
$\mathrm{VOCs}\left(\mu \mathrm{g} / \mathrm{m}^{3}\right)$ & 121467.00 & 1293.34 & 1053.34 & 600.00 & 373.33 \\
$\mathrm{TEMP}\left({ }^{\circ} \mathrm{C}\right)$ & 30.85 & 30.20 & 24.00 & 24.00 & 25.00 \\
$\mathrm{RH}(\%)$ & 20.50 & 21.00 & 23.50 & 28.50 & 29.00 \\
$\mathrm{~W} / \mathrm{S}(\mathrm{m} / \mathrm{s})$ & 0.40 & 0.35 & 0.90 & 1.00 & 1.05 \\
\hline
\end{tabular}

Where, TEMP is Temperature in ${ }^{\circ} \mathrm{C}, \mathrm{RH}$ is relative humidity in $\%$ and W/S is Wind speed in $\mathrm{m} / \mathrm{s}$.

Table 3: The mean distribution of all the pollutants monitored.

where: $\mathrm{Lp}=$ The PSI for the polluted $\mathrm{P}$; $\mathrm{Cp}=$ The actual ambient concentration of $\mathrm{P} ; \mathrm{BPhi}=$ The breakpoint in Table 1 greater than or equal to $\mathrm{Cp}$; $\mathrm{BPlo}=$ The breakpoint in Table 1 less than or equal to $\mathrm{Cp}$; Lhi=The sub index values corresponding to BPhi; Llo=The sub index values corresponding to BPlo.

\section{Results}

The PSI of $\mathrm{SO}_{2}$ in the study area is high, confirming that members of the sensitive group may experience more serious health effects. $\mathrm{NO}_{2}$ and $\mathrm{PM}_{10}$ recorded very high PSI which triggers health challenges. This is consistent with Goyal and Anikender report on mathematical modelling of air pollutants [9].

\section{Discussion}

The various activities of abattoir operators in Ogbor hill Aba have led to the emission of obnoxious gases which alters he atmospheric composition in the study area. The criteria pollutants considered in this study showed elevated concentration likewise other gases monitored such as $\mathrm{H}_{2} \mathrm{~S}, \mathrm{CO}, \mathrm{CO}_{2}, \mathrm{HCl}$, and VOCs. Thus, the more concentration 
Citation: Ubuoh EA, Uchendu UI, Kanu C (2017) Characterization of Atmospheric Gaseous Components in Abattoir Operation Site in Ogbor-Hill Aba, Abia State, Nigeria. J Environ Anal Toxicol 7: 474. doi: 10.4172/2161-0525.1000474

Page 3 of 4

\begin{tabular}{|c|c|c|c|c|c|c|}
\hline S No & Air Pollutant & Psi & WHO Standard & FMENV Standard & NAAQS Standard \\
\hline 1 & $\mathrm{SO}_{2}\left(\mu \mathrm{g} / \mathrm{m}^{3}\right)$ & 588.81 & 20 & 83 & 80 \\
2 & $\mathrm{NO}_{2}\left(\mu \mathrm{g} / \mathrm{m}^{3}\right)$ & 878.62 & 40 & 50 & 100 & High \\
3 & $\mathrm{PM}_{10}\left(\mu \mathrm{g} / \mathrm{m}^{3}\right)$ & 585.91 & 20 & 50 & 150 \\
\hline
\end{tabular}

Table 4: The pollutant standard index (PSI) of the criteria pollutants.

\begin{tabular}{|c|c|c|c|c|}
\hline S No & Air Pollutant & Mean & S $^{2}$ & S \\
\hline 1 & $\mathrm{SO}_{2}\left(\mu \mathrm{g} / \mathrm{m}^{3}\right)$ & 613.25 & 74381.25 & 272.23 \\
2 & $\mathrm{NO}_{2}\left(\mu \mathrm{g} / \mathrm{m}^{3}\right)$ & 699.05 & 38023.24 & 195.00 \\
3 & $\mathrm{PM}_{10}\left(\mu \mathrm{g} / \mathrm{m}^{3}\right)$ & 1966.67 & 528890.89 & 28.32 \\
\hline
\end{tabular}

Table 5: The mean, standard deviation and coefficient of variance of the criteria pollutants.

of gases in the atmosphere can as well affect the health of the abattoir operators as well as public. Erratically, the atmospheric environment is altered thus increasing the concentration levels of photochemical oxidants.

The mean concentration of $\mathrm{SO}_{2}$ is $858.33 \mu \mathrm{g} / \mathrm{m}^{3}$ and it exceeds the recommended standards by NAAQS. This signifies that continuous emission of $\mathrm{SO}_{2}$ in Ogbor hill Aba will aggravate the health status of the people with existing heart or respiratory illness, other healthy individuals may experience discomfort. Comparing this value to $\mathrm{WHO}$ and FMENV guidelines which are given as $20 \mu \mathrm{g} / \mathrm{m}^{3}$ and $83 \mu \mathrm{g} / \mathrm{m}^{3}$ respectively, the elevated mean of $\mathrm{SO}_{2}$ to the rate of $613.25 \mu \mathrm{g} / \mathrm{m}^{3}$ far exceed these standards and immediate attention is required. According to WHO [10], high concentration of $\mathrm{SO}_{2}$ in the ambient air irritates the skin and mucous membrane of the eye, nose, throat and lungs. An increase in the rate of exposure increases the risk of inflammation and irritation of the respiratory system, especially during heavy physical activities. High concentration of $\mathrm{SO}_{2}$ can affect lungs function, worsen asthmatic attacks and aggravate existing heart diseases in the sensitive group.

Emission that leads to high concentration of $\mathrm{SO}_{2}$ generally also leads to the formation of other SOx. Control measures that reduces $\mathrm{SO}_{2}$ can generally be expected to reduce people's exposure to other gaseous SOx. This may have the important co-benefit of reducing the formation of fine sulphate particles which pose significant public health issue. The indiscriminate discharge of untreated abattoir effluent into the $\mathrm{Aba}$ river and the poor management of animal waste caused by the emission of $\mathrm{NO}_{2}$ at an alarming rate. the mean value of $\mathrm{NO}_{2}$ is 699.05 $\mu \mathrm{g} / \mathrm{m}^{3}$ is high, the PSI value is $878.62 \mu \mathrm{g} / \mathrm{m}^{3}$ which is elevated and can pose serious health threat to the public on constant exposure. This conform with Aneja et al. [11] which states that an increasing evidence show that greater size and intensity of abattoir and concentrated animal feeding operations increases the emission of odorous compounds such as $\mathrm{NO}_{2}$ and $\mathrm{SO}_{2}$. Currently, scientific evidence by the US EPA [12] links short term $\mathrm{NO}_{2}$ exposure ranging from 30 minutes to 24 hours with adverse respiratory effects including air way respiratory symptoms in individuals with asthma.

The NAAQS rated the respiratory quantity of $\mathrm{NO}_{2}$ as $100 \mu \mathrm{g} /$ $\mathrm{m}^{3}$, whereas WHO and FMENV have their guidelines as $40 \mu \mathrm{g} / \mathrm{m}^{3}$ and $50 \mu \mathrm{g} / \mathrm{m}^{3}$ respectively, these range cannot be a proximity of the result obtained from the study area of $893.34 \mu \mathrm{g} / \mathrm{m}^{3}$, nor compared to the mean value of $699.05 \mu \mathrm{g} / \mathrm{m}^{3}$. A recent study by WHO show a connection between breathing elevated short term $\mathrm{NO}_{2}$ concentration and increased visits to emergency department and hospital admission for respiratory issues especially asthma. The sum of nitric oxides and $\mathrm{NO}_{2}$ in the atmosphere is commonly called nitrogen oxide or NOx. Other oxides of nitrogen including nitrous acid and nitric acid are part of the nitrogen oxide family. While EPA's NAAQS covers these entire family, $\mathrm{NO}_{2}$ is the component of greatest interest and indicator of the large group of nitrogen oxides.
The main source of $\mathrm{PM}_{10}$ from the abattoir operation is the high rate of carcass combustion and the process of dehairing. A close physical observation of the study area shows a cloudy weather during major activities at the abattoir and smoke is readily emitted simultaneously. These particulates do not only emit from the carcass burning or meat processing but also the wood used in dehairing, cooking and drying of meat.

The estimated mean from the result of $1966.67 \mu \mathrm{g} / \mathrm{m}^{3}$ for $\mathrm{PM}_{10}$ exceeds the set-out standard by NAAQS $\left(150 \mu \mathrm{g} / \mathrm{m}^{3}\right)$, WHO $\left(20 \mu \mathrm{g} / \mathrm{m}^{3}\right)$ and FMENV $\left(50 \mu \mathrm{g} / \mathrm{m}^{3}\right)$, this constitute a serious risk factor for public health. In line with report by FEPA [8], the size of the particles is directly linked to their potentials for causing health problems. Small particles less than 10 micrometres in diameter pose the greatest problem because they can get deep into the human lungs and some may eventually get into the blood stream, therefore exposure to such particles can affect the lungs and heart.

Further analysis of the result was done using the ANOVA, after being subjected to the statistical test, several air pollutants exerted significant influence on the ambient air quality. Considering the criteria pollutants at $\mathrm{P} \leq 0.01 \mathrm{SO}_{2}$ and $\mathrm{NO}_{2}$ exerted a significant effect on the composition of the ambient air quality in the study area. $\mathrm{PM}_{10}$ though recorded the highest values have no significant effect at $\mathrm{P} \leq$ 0.01 . Further verification at $\mathrm{P} \leq 0.05$, it has a significant effect on the ambient air quality. Therefore, $\mathrm{SO}_{2}$ and $\mathrm{NO}_{2}$ proved significant at $(\mathrm{P} \leq$ 0.01 ) on the ambient air around the study area where $\mathrm{PM}_{10}$ was found to be significant at $\mathrm{P} \leq 0.05$, this proved that there is significance effect of abattoir operation on the ambient air quality in Ogbor hill Aba.

A critical look at the result, climate variables such as temperature, relative humidity and wind speed have crucial impact on the ambient concentration level of these pollutants. At a high temperature, the pollutant gain more kinetic energy and can travel (disperse) faster at a higher velocity and wind speed. An increase in relative humidity tends to increase their molecular mass and reduces their concentration at the ground level (ambient). The wind speed helps in spreading the gases far and near depending on their molecular weight and velocity of the prevailing wind. Due to the nature of the landscape in the area, the pollutants cannot disperse or be carried far away from the abattoir because the whole region is on a valley. The higher the temperature, the higher the concertation of the pollutants, the higher the relative humidity, the lower the concentration and vice versa, whereas wind speed facilitates their dispersal.

\section{Conclusion}

The result obtained from this study revealed that air quality was altered by various activities in the abattoir such as indiscriminate disposal of animal waste and untreated effluent discharge on the Aba river, meat processing, dehairing, burning of carcass etc. the criteria 
Citation: Ubuoh EA, Uchendu UI, Kanu C (2017) Characterization of Atmospheric Gaseous Components in Abattoir Operation Site in Ogbor-Hill Aba, Abia State, Nigeria. J Environ Anal Toxicol 7: 474. doi: 10.4172/2161-0525.1000474

Page 4 of 4

pollutants are responsible for the unpleasant odour and health risk of the public around the study area. Most of the gaseous pollutant monitored exceeded their established standards by WHO, NAAQS and FMENV respectively. Results also showed a strong elevation among the identified gaseous pollutants, three of these are namely $\mathrm{SO}_{2}, \mathrm{NO}_{2}$ and $\mathrm{PM}_{10}$ were mostly predominant as they recorded the highest level of exceedances during the monitoring period. The result was further subjected to ANOVA and it was found that $\mathrm{SO}_{2}$ and $\mathrm{NO}_{2}$ exerted significant effect at $\mathrm{P} \leq 0.01$, whereas $\mathrm{PM}_{10}$ show a significant effect at $\mathrm{P} \leq 0.05$. However, the overall assessment of the ambient air quality in the study area indicates a result that would be described as unhealthy by various health standard. Climatic variables such as temperature, relative humidity and wind speed also contributes to an extent to this variability of the level of measured pollutant.

This study recommends that agricultural industries should develop and utilize the various waste products generated from abattoir operation. Relocation of the abattoir to a government designated area would help reduce dispersion of pollutants to residential area. There is need for further epidemiological research in the study area to ascertain the level of impact of a long-term exposure from the abattoir emission on the local residence.

\section{References}

1. Abulude FO (2006) Analysis of suspended air particulates along four sawmills in Nigeria during the wet and dry seasons. Journal of Engineering and Applied Sciences 1: 224-226.
2. Smil V (2005) Carbon - Nitrogen - Sulphur; Human interface in grand biospheric cycle. Plenum Press, New York, USA, p: 459.

3. AEA (2002) The emission of air pollutants from abattoir operation. Abattoir site as a source of air pollution. UK.

4. Environmental Protection Agency (EPA) - Guyana (2001) Environmental protection agency draft document January 2001. Operational guidelines for abattoir/slaughter houses.

5. FBF Organics (2009) Chicken abattoir effluent ease study.

6. Ubuoh EA, Akhionbare SMO (2011) Effects of Pig Production on Ambient Air Quality of Egbeada in Mbaitoli Local Government area of Imo State, Nigeria. Journal of Sciences and Multidisciplinary Research (JSMR) 3: 8-16.

7. James RW, Allison K (1999) Abattoir, slaughterhouse and poultry processing industries, their impact on the ecosystem. A Journal of Environmental Science, pp: 212-219.

8. Federal Environmental Protection Agency (FEPA) (1999) National guidelines for Environmental Audit in Nigeria. Federal Government Press, Abuja.

9. Goyal P, Anikender K (1999) Mathematical modelling of air pollutants; an application to India. Centre for Atmospheric Sciences, Indian Institute of Technology, Delhi, India, pp: 116-117.

10. WHO (2000) Air Quality for Europe. World Health Organization Regional Office for Europe 2002. 2nd edn. Copenhagen. No. 91. WHO Regional Publication European Series.

11. Aneja VP, Wang B, Tong DQ, Kimball H, Steger J (2006) Characterizing of major chemical components of fine particulate matter in North Carolina. Air Waste Management Association 56: 1099-1107.

12. US Environmental Protection Agency (2003) Toxicological review of hydrogen sulphide. CAS No. 7783-06-4; EPA/635/R-03/005; US EPA, Washington DC, USA 